\title{
Sex, Drugs and the IMF: Some Implications of "Structural Readjustment" for the Trade in Heroin, Girls and Women in the Upper Mekong Region
}

\begin{abstract}
A highly informed and detailed analysis of the intimate relationship between structural adjustment programs and the thriving drug and sex trade in the Upper Mekong Region of Thailand, providing additional perspective on illicit trafficking and trade in the larger Southeast Asian context. Attention is specifically drawn to the harsh and disproportional impact of IMF economic policies upon women and girls, also acknowledging the great importance of a wider understanding of international traffic in persons, in terms of migration problems and labour exploitation, rather than solely in relation to sex.
\end{abstract}

\section{Précis}

Une analyse très fouillée de la relation intimequis'établit entre les programmes d'ajustement structurauxet le florissant commerce de la drogue et des faveurs sexuelles dans la région du Haut Mékong en Thailande; ce commerce ayant comme principale caractéristique de fournir un aperçu complémentaire sur toutes lesfor-

David A. Feingold, Ph.D., is a research anthropologist and filmmaker associated with the Ophidian Research Institute. Hehas recently completed a three-film project on land mines in Mozambique for UNICEF, and seroes as a consultant on Culture and Communication for UNESCO/PROAP. He is also a consultant for the UNESCO research project on cultural factors in the transmission and prevention of HIV/ AIDS, and serves on the UN Working Group on Trafficking.

This paper is part of a larger research study of the trade in minority girls and women from Yunnan, Burma (Myanmar) and Laos into Thailand. Research for this project is being conducted under grants from the John $D$. and Catherine $T$. MacArthur Foundation, the Else Sackler Foundation (two grants), and the Spunk Fund Inc. The project has received additional support from the United Nations Educational, Scientific and Cultural Organization (LNESCO).

\author{
David A. Feingold
}

mes de trafics illicitedansle contexteplus large de l'Asie du Sud-Est. Le caractère cru et disproportionné de l'impact des politiques économiques du F.M.I. surla vie des femmes et des jeunes filles de la région est examiné avec une attention particulière. Il est aussi tenu compte de l'importance que revêt une compréhension plus large de la traite des blanches, nommément de par la description de la situation en termes de problemes migratoires et d'exploitation de la force de travail,plutôt que strictement en termes de questions de nature sexuelle.

\section{Introduction}

The financial crisis, which began in Thailand, has tumbled economies throughout Asia. The strong (e.g., Japan) have been hurt; the weak (e.g., Indonesia, Burma/Myanmar) have been devastated. The prescription of the international community has been the "strong medicine" of "reforms" which have raised the prices of necessities, squeezed the agricultural sector, crunched credit, and slashed employment in countries with few social safety nets. Thailand-the travel brochures' "Land of Smiles" - worries about its rising suicide rate. Television pictures of food riots and farm lootings in Indonesia and tearful Korean families leaving the children they can no longer feed in orphanages make manifest the deadly side-effects of the prescription. They tend to undermine the bland assurances of IMF bureaucrats, immune to criticism, that all will be well, if only democracy does not prevent leaders from "staying the course." Even Business Week reported an Asian "social backlash," and worried: "Economies are on thebrink of depression - and the resulting popular rage could force leaders to pullbackfrom reform." 1

The irony of gray-suited Westerners jetting business class (at least) to Asia to preach the virtues of belt-tightening, austerity and hard work to peasant farmers and displaced workers is hard to miss. Even before the Asian Crisis, the British economist Paul Ormerod noted:

Austerity and discipline are the hallmarks of the favoured policies of the IMF throughout the world, yet its own salary bill has risen by 38 percent in the last two years, and is budgeted to rise by a further 22 percent in $1994 .^{2}$

In the face of the realities of Asia, other economists are coming to question the efficacy the "one for a man, two for a horse" patentmedicine policy prescriptions of the $\mathrm{MMF}{ }^{3}$ Moreover, women and girls have been disproportionally impacted by these policies, raising questions both of equity and long-term social stability.

However, two important S.E. Asian industries are well-placed to benefit from the present economic policies. This paper will begin to explore the effects of these policies on the two industries which have shown themselves best able to respond to the changing conditions of the free market-commercial sex and illicit drugs. It will also explore the broader questions of the impact of development policies on the trade in women-particularly, minority women-in the Upper Mekong Region. ${ }^{4}$

\section{The Upper Mekong Region}

The UpperMekong region has formed a coherent cultural, ecological and economic zone for centuries. Historical trade and migrationnetworks have continued into the present. The opening of borders to tourism and trade in the region has increased the flow of populations across borders for trade (licit and illicit) and labour, with major implications for both the sex and drug industries and the epidemiology of HIV/AIDS. It is an area characterized 
by ethnic diversity, cultural pluralism and linguistic complexity. In Yunnan alone, with a population of 40 million people, there are 13 million minority people belonging to 26 ethnic groups. The lowland Lao are barely a majority in the LaoPDR. These minorities cross-cut political boundaries. For example, the Akha, a traditionally highland people, speaking a Tibeto-Burman language, are found in China, Burma, the LaoPDR, and Thailand. An Akha from Luang Namtha in Laos will communicate more easily and have more in common with another Akha from Chiangrai, Thailand than with a Lao two hours walk down the mountain.

There are a vast number of distinct languages from different language families. Many of these are unwritten languages with no indigenous scripts. While some have transcriptions developed by Western missionaries, these are frequently based on the Roman alphabet and not widely used. The Chinese havealso developed transcriptions, but these are also not widespread. While there is considerable multilingualism even (or especially) among thenon-literate people of the region, minority women are notably less likely to command either the national language or other minority languages. This means that they are less likely to be adapted to non-traditional employment, and less likely to have access to accurate information about the wider world. Therefore, highland women are particularly vulnerable to trafficked or non-trafficked sex work and to the related threat of HIV/ AIDS.

The Upper Mekong region contains zones of high HIV infection and transmission, and areas vulnerable to explosive expansion of HIV/AIDS. ${ }^{5}$ At present, HIV/AIDS is a major threat to the economic and social viability of the region. In particular, it is a threat to the physical and cultural survival of the highland minorities. In Thailand, the HIV/AIDSepidemicfirstmatured in the North. Of the cumulative AIDS cases, the largest proportion (36\%) are in the provinces of the upper North, compared to 9.5 percent for Bangkok. ${ }^{6}$ In China, the Ministry of Health reports that the first HIV/AIDS cases appeared in Yunnan in 1985 and that as of 1997, only Yunnan province has reported more than 1000 cases, mostly among minorities. ${ }^{7}$ In the Lao PDR, data are limited. It is clear, however, that the increase in tourism, the expansion of road networks connecting China, Vietnam and Thailand through Laos, poverty and proximity to high HIV/AIDS areas pose clear risks for an epidemic that the country is ill-equipped to combat. Just as the HIV/AIDS epidemic in Thailand moved from being an "IV Drug Use Epidemic" to being a "Sexual Epidemic," China is starting to experience a transition in primary mode of transmission from IV drug use to heterosexual intercourse. Political and social policies in Burma are working to guarantee an HIV/AIDS epidemic nearly without parallel in Southeast Asia.

\section{Women as Commodities: Trafiic and Trade}

Tounderstand the structural underpinnings and implications of the flow of women into the Thai sex industry, it may be useful to distinguish conceptually between "traffic" and "trade." While there is no universally accepted definition of trafficking, the Global Alliance against Trafficking in Women (GAATW) has developed a pragmatic and effective one:

Trafficking in women: All acts involved in the recruitment and/or transportation of women within and across national borders for work or services by means of violence or threat of violence, abuse of authority or dominant position, debt bondage, deception or other forms of coercion.

Under this definition, "trafficking" involves discrete and overt acts against women, which could, in theory, beidentified and sanctioned. "Trade," on the other hand, is merely descriptive of the exchange involved in the entry into sex work, and makes no judgement about the cause or process of that entry. All trafficking is trade, but not all trade is trafficking. Economic, political, and social policies may promote or hinder either or both.
Byany measures-and itmustbe recognized that those measures are woefully imprecise-the international traffick in persons is continuing a process of expansion, specialization, and differentiation that has grown exponentially over the last decade. Increasingly sophisticated networks have developed which rival illicit drug trafficking organizations in global reach, profits, and efficiency. ${ }^{9}$ In any smuggling operation, the size of the product determines the methods of transport. Unlike drugs, which are easily concealed, human beings are a fragile cargo that calls attention to itself. Therefore, from the point of view of the smuggler, corruption is nearly always less costly than concealment. Most trafficked persons are moved across international boundaries in more or less plain view. This means that corruption is an essential, rather than merely facilitative, part of the process. It may also mean that given the world-wide trend toward tighter immigration criteria and the drive to cut labour costs in the global market, the corruptive influences of the traffick in persons will exceed even that of the trade in illicit drugs.

While sexual trafficking certainly constitutes an important and profitable sub-sector of the international traffick in persons, it should be emphasized that most trafficking is for non-sexual forms of labour. Similarly, although the majority of those trafficked for sex are women and girls, the majority of trafficked women and girls are not trafficked for sex. Recently, more and more international attention, if little effective policy, has focused on the traffick in women. ${ }^{10}$ However, while specialized international organizations, such as the International Migration Organization (IMO) and the International Labor Organization (ILO), see trafficking in the larger context of migration problems or labour exploitation, most of the attention has focused on sex. This is understandable. As headline-grabbers, girls sold into sexual slavery in brothels are-topically-sexier than girls (and boys) working as near-slaves on tapioca plantations. 
In a similar vein, the sexual trafficking of women and of children are often conflated as if they were the same phenomenon, tobe addressed with the same remedies. ${ }^{11}$ While such approaches may appear to provide useful rhetorical weapons for public mobilization, they often obscure more than they clarify. In the end, this helps neither the women, nor the children. For the international community, the linkage of trafficking to prostitution, sexual exploitation and coercion is more comfortable in the case of children because they are deemed innocent. Children (generally, those under eighteen) are defined by international treaty and much national law to be incapable of giving consent toengage in commercial sex; ;2 hence, complex and disquieting (to most adults) questions of choice, agency, options and volition are subsumed. ${ }^{13}$ In contrast, while some women are coerced or deceived into sexual labour, many adult women choose sex work as a rational (not necessarily desirable) strategy for economic survival for themselves and their families.

Sex work is more highly rewarded than any occupation available to uneducated (and-in present conditions-even many educated) women. Even before the present crash, sex work was far better rewarded than alternative sectors. Fifteen years ago, earnings for what was called the "special service" sector in Thailand averaged 5,000 baht per month, while most female migrants in other occupations were earning less than 840 baht per month. ${ }^{14}$ In 1996, Kritiya and Phornsuk studied a sample of thirty-three women sex workers from Burma and China. Theaverage monthly income was 5,008 baht, of which they wereable to send home 1,283 baht. In contrast, other occupations (domestics, etc.) earned 1,957 baht per month and were able to remit 563 baht. ${ }^{15}$

\section{The Current Crisis: Burst Bubbles and Faded Hopes}

The period since July 1997 has been a time of major economic upheaval in Southeast Asia: The Thai baht-which was twenty to the dollar from 1961 until the early eighties and twenty-five to the dollar until June of this year-fell as low as the mid-fifties to the dollar, before recovering to around thirty-seven to the dollar at present. Because of the large outstanding dollar denominated loans, it is unlikely that the present rate can be maintained. The demand for U.S. dollars to pay these loans will likely drive the baht still lower in the future, despite economic "reforms" imposed on Thailand by the MMF.

The fall in the currency, the collapse (or government closure) of shaky financial institutions, high interest rates and increased taxation imposed under the IMF agreement, as well as the higher cost of any imported goods havecaused massive layoffs in a country that has only seen growth for more than a decade. The stories in newspapers have featured those called "The Formerly Rich" having garage sales for BMWs and Mercedes-Benz (Thailand was formerly the eighth largest market in the world for Mercedes-Benz), and the former investment banker who has started a sandwich street vending venture. However, while these stories sell newspapers and attract $\mathrm{CNN}$, the more significant long-term dangers are the precipitous rise in gasoline prices and, even more telling, the increased cost of rice. As with the start of many economic crises, the distress of the rich in the capital is noticed, while the pain of the poor in the countryside is ignored.

It should be noted, however, that for the hill peoples of Thailand, the "boom" of the past decade has been something of a bust. For the highland minorities, the years of dramatic economic growth in Thailand were years of shrinking economic opportunities and increasing social dislocation. Without citizenship and withoutland tenure, the majority of the tribal population of Thailand was sinking, while much of the rest of the country prospered. ${ }^{16}$

The crash has affected Laos and Burma (Myanmar) as well as Thailand, but for quite different reasons and with quite different results. Half of Lao PDR (Peoples Democratic Republic) reserves are held in baht. Over the past year, the Lao kip has fallen from around 1,000 to thedollarbefore the crash, to 1,700 to the dollar in April, to 2,600 to the dollar in August. At present, the rate stands at about 4,600 kip to the dollar. In addition, Thai investment in Laos has come to a virtual standstill. Yet, the Lao economy does not appear to have fallen as much as the Thai, at least partially, somesuggest, becauseit did nothave far to fall. Much of the countryside remains partially isolated from many of the market forces, which have penetrated even the most remote regions of Thailand. Many of the consumer imports, particularly in the North, come from China, and have not increased in price commensurate with the drop in value of the kip vis$\grave{a}$-vis the dollar. However, civil servants, the business sector, and the urban population in general are certainly being squeezed. In addition, many within the government are becoming less enchanted with the free market and the opening of Lao society in general. Many of the older, more conservative Party officials have always been suspicious of the expansion of economic, social and-most of all-political liberalization. As long as the trajectory of the economy was up, they were constrained by the apparent success of new, more open policies. The collapse of the "Asian Miracle," however, has given new impetus to forces of repression that were always present.

If economic insularity and authoritarian rule were truly protective, Burma would be better off than any nation of the Southeast Asian mainland. In fact, what little national economic activity existed in Burma has virtually ground to a halt. One year ago last June, one dollar equalled about 100 Burmese kyat. By the end of June 1997, a dollar equalled around $200 \mathrm{kyat}$. In the middle of July, the pricejumped from 200 to 340 in one day, and trading stopped. The rate recovered to about 280 , where it remained until recently. (The present rate is well over 300 .)

The reasons for the collapse and partial recovery of the kyat are complex and very different from that of the baht. Burma maintains a dual monetary system; printing both kyat-the national currency-and FEC (Foreign Exchange Certificates), denominated in dollars. 
This gave the regimean effective license to print U.S. dollars, as long as people believed themyth. FECswerenotbacked by anything. To some extent, however, Burma's currency problems (if not her economy as a whole) have been helped by the collapse of much of the cross-border trade with Thailand. This has meant a lower demand for dollars to purchase tradegoods.

Our most recent research along the China-Burma border shows a complete collapse of legitimate trade in the previously booming area of Ruili. What had formerly been a region of thriving crossborder exchange of raw materials from Burma for manufactured goods from China is now limited to narcotics and girls to supply this Chinese gambling centre. (Ruili is one of the few places in China where gambling is legal.) Some of the most important heroin factories in the world can be seen from China just across the border in Burma. Not surprisingly, drugs are easily available in this region of China, despite harsh penalties and great concern on the part of the national government. This is particularly significant in that, like Thailand, the HIV/AIDS epidemic in China started as an I.V. drug epidemic and is now turning into a sexual epidemic. Unaccompanied men are now coming from all over China to gamble in Ruili, using the sexual services of cross-border recruits, and returning home. Moreover, condom use is very low.

In human terms, the inflation of the Burmese kyat has turned a bad economy into an impossible one. A low-level civil servant is paid 700 kyat per month; a 10 $\mathrm{kg}$ bag of rice costs $1,100 \mathrm{kyat}$. This situation guarantees corruption and places impossible burdens on families, making daughters more vulnerable to migration to Thailand and China for sex work. The cost of girls in Ruili gives some measure of the economic desperation across the border: $10 \mathrm{rmb}$ for a "low class" girl up to $50 \mathrm{rmb}$ for a "high class" one. This is equivalent to about $\$ 1.25$ to $\$ 6.25$, respectively.

In addition, the collapse of much of the economic activity in Northern Thailand has severely restricted the alternative opportunities for migrant labour fleeing the conditions in Burma. A case in point are the Shan girls and women who came to Chiang Mai seeking work on the many construction projects that flourished in that city. Today, these projects have come to a standstillthere is no construction work in Chiang Mai, for migrants or anybody else. A largenumber of Shans remain stranded, unable to find legitimate work, unable or unwilling to return home. These young women are particularly susceptible to recruitment into the sex industry, and their undocumented status makes them especially vulnerable to the worst types of exploitation.

\section{The Sex Industry-Adaptation to Change}

The long-term effects of the Asian economic collapse on the net consumption of sexual services are, as yet, unclear. At the top end of themarket, anumber of socalled "member clubs" have closed in Bangkok. These are expensive, more or less exclusive clubs, providing entertainment and indirect sexual services in "luxurious" surroundings. The women who work in them are chosen both for their beauty and for their ability to charm customers. They are extremely well paid, and few trafficked women ever work in these establishments. The member clubs, night clubs and bars that catered exclusively to Japanese have been particularly hard hit by the withdrawal by Japanese companies of many representatives working in Thailand. Moreover, those who have remained are entertaining less extravagantly than in the past. Club memberships were often paid for by companies as a job benefit for hard-working salary men abroad and as a place to entertain customers and government officials. In moves to trim costs, member clubs and golf clubs have all suffered.

However, less lavish entertainment complexes seem to be flourishing, and the most recentsurvey of sex workers by theSTDControl Division of the Ministry of Public Health found no decrease in thenumber of CSWs since the start of the crisis (but no significant increase either).
The crash of the Thaibaht, the hyperinflation of the Burmese kyat and the drop in the Lao kip are having profound effects on the regional economies of the Upper Mekong. It is not yet clear, however, what will be the effect on the economics of the regional sex industry in general, and on the participation of minority girls and women in particular? In the recent past, factories in Thailand have absorbed women (particularly from Northeast Thailand) who, in former times, supplied the sex trade. The recent economic meltdown and, more particularly, the policies designed to cope with it have resulted in widespread layoffs. These layoffs have disproportionally impacted womennot because the industries have been directly discriminatory, but because they are capital dependent during a credit crunch. If these Thai women are forced to take up sex work, it is unclear whether they will displace foreign and minority women, or bring down the price of services. Many will choose to follow earlier migrants to higher paying sex work in Switzerland, Germany, Canada, or Japan. ${ }^{17}$

Moreover, the increase in fighting along the Thai-Burma border has resulted in still greater population displacement and cross-border migration at precisely the time when Thailand sees itself as most threatened by migrant labour. Workers come from as far away as Myitkyina in Kachin State in the hopes of day labour in the fields, or, with luck, some more permanent job. Even though the work is hard and the pay low, a couple of days work will cover their travel costs and reap a profit greater than is available in Burma. Many of the women who come for agricultural or household work end up in sex work because the pay is far better and they are desperate to help their families.

I believe it is essential to investigate the impact of these and other economic changes on the structure and dynamics of the sex industry. In simple terms, is commercial sex a luxury or a commodity? Will people with less disposable income chose to continue their level of sexual consumption (itbeing one of the 
few pleasures that they can still afford), cut down their consumption level, or move "down market" (i.e., frequent lower priced establishments)? Does commercial sex operate according some version ofSay's Law of Markets; i.e., that supply generates its own demand? Given the importance of the sex industry to the Thai economy, these are not trivial questions. Any policy formulation which attempts to encompass the reality of the sex trade must address the underlying economic structure of that trade, as well as the dynamics of its adjustment to changing economic and social conditions.

Our research has found that the entry of girls into sex work involves a complex of interlocking networks-both formal and informal, commercial and noncommercial-criss-crossing borders throughout the Upper Mekong region. There is a flow of females moving north in one area; south in another. Tai Neu girls go into China, while Dai girls from the Sip Song Panna (Xishuangbanna) region of China travel down through Burma to Thailand. Some are actually kidnapped and/or sold; that is, "trafficked", in the traditional sense of the term. Others are victims of deceptionpromised restaurant, household or factory jobs, only to be lured or forced into sexwork.Most, however, make"voluntary" choices to start their journeys, though these choices are often predicated upon harsh economic conditions at home and scant knowledge of the outside world. Research indicates that most are not so much fleeing abject poverty and political oppression (as in Burma), butchasing a better, more excitinglife. Much of the impetus can be described as the lure of "bright lights, big city." Many of the girls believe that the streets of Thailand are "paved with gold;" that life is more exciting than in their villages; and that they will be part of a dominant population, instead of a minority as they are in China. Part of the "push factor" is the "to get rich is glorious" attitude that pervades China, in which rural people see themselves as shut out of the opportunities for material advancement. However they start out, in the course of their joumey to
Thailand, the women frequently come to depend on one or more of these networks.

Wehavelocated the LukMoo(Piglet) Network, who are responsible for about 50 percent of the girls and women smuggled into Thailand from Shan States, China and Laos to work in brothels. There are also other networks, such as the Kabuankarn Loy Fah ("Floating in the sky" Network) specializing in girls for restaurants and Karaoke bars. Much like illicit drug networks, each of these networks depends on financing and political protection to operate. Standard bribes must be paid to move girls across borders and through police checkpoints. Profit maximization dictates transporting girls through the fewest numbers of checkpoints. This is the great appeal of using the Mekong River.

The Pigletnetwork has tried a variety of means to smuggle girls to supply to the brothels. Although the Mekong River transporthas beenhalted, the Piglets have turned to overland trafficking routes through Tachilek (Burma) toMae Sai (Thailand). From there, girls can be moved around the country, some are traded all the way to Malaysia. The Piglet financier never involves himself directly in trafficking. He assigns agents to work on his behalf, but if an agent is arrested by the police, the financier will intervene-using his political power to secure the agent's release.

Over the past eighteen months, changes have taken place, which have resulted in a movement from so-called directsex work (brothels) to indirectsex work. This has resulted in better working conditions for the women in the North, but created more of a public health problem because of less control. Thailand is the only country in the region tobring its HIV infection rate under control. In Burma, Laos, and China, HIV infection rates are climbing, but in Thailand new infections have fallen dramatically in the last five years. (Of course, the number of AIDS cases is still increasing at a horrifying rate due to past HIV infections.) Even in Thailand, however, new threats are emerging because of the economic crisis. One comerstone of the Thai pubic health success has been the distribution of free condoms by the Ministry of Public Health. This program is now at risk because of budget cuts, and medical officials fear that it will not survive the year.

\section{Illicit Investment: Growth and Survival through Sex and Drugs}

In many parts of the world, illicit activities provide capital, both directly and indirectly, for legitimate investment. This becomes more significant in communities or countries lacking sufficient capital and credit mechanisms. It is most important, however, either in times of rapid economic expansion, where capital resources do not keep pace with perceived investment opportunities; or in times of severe contraction, when a credit crunch can cut off other sources of investment.

During the 1970s, the development of Northern Thailand was fuelled, not surprisingly, by the most important regional industry-opium production. Not only did most of Burma's massive production of opium (much of it converted to morphine base or heroin) pass through Thailand to the rest of the world, but also Thailand provided a safe, relatively stable environment for both direct and indirect investment of the profits derived from the trade.

For example, in Chiang Mai, some sixteen new hotels were built between 1977 and 1981 . This is not to say that each and every hotel was financed and built by a local "opium warlord," handing over bags of cash in his shadowy incense-smoked lair. Rather, it is that the proceeds of the trade provided the necessary investment capital that was otherwise absent from the local economy. The banking systems-the modern, formal system as well as the traditional, informal ones-accumulated capital from the deposits of those involved directly or indirectly with the drug trade. ${ }^{18}$ To cite a case in point, General Li Wen Huan, the KMT general who arguably controlled more opium than anyone else in this century, was a valued customer of the Chiangmai branch of the Bangkok Bank of Commerce. Before a recent and scandalous collapse (not involving drug money), 
the $\mathrm{BBC}$ was considered a quite respectable institution. Other "respectable" banks in Thailand-including some well-known international ones-have benefited from similar depositors.

At present, to the extent that one can speak of local investment in Burma, that investment derives from the opium trade and (more recently) the trade in amphetamines. Lo Hsing-han was a major opium trafficker who, in the early 1970 s, joined a coalition of Shan revolutionary groups that offered to sell a third of the world'sillicit opiates to the United States or the UN for about $\$ 12$ million. He was betrayed by his high-ranking contact within the Thai government of the time, who was afraid that Lo would reveal the details of a corrupt relationship that was vastly profitable to both sides. Arrested and returned to Burma tostand trial for a variety of political (but not narcotics) offences, most observers believed that it was unlikely Lo would see the light of day again. Today, he reportedly owns transport lines, the Traders Hotel in Rangoon (Yangon), as well as having numerous other hotel and banking investments. The U.S. State Department reported that 15 percent of all foreign investment in Burma goes through a company owned by Lo's relatives. ${ }^{19}$ The hotel business seems to have an appeal to many at the upper levels of the opium trade. ${ }^{20}$

The major consequence of the capture of Lo Hsing-han was to allow the now well-known Khun Sa to capture control of much of the trade. The socalled "King of Opium" of the "Golden Triangle" combined revolutionary politics and business acumen to control and tax-but not own-a major portion of the opium production of Burma and to frustrate the flailing efforts of the U.S. government to capture him. Two decades of large rewards for his capture, support for his enemies and a Brooklyn indictment left Khun Sa quite unscathed, and demonstrated (yet again) the impotence of moral puffery as a substitute for effective socio-economic policy. Having negotiated a "surrender" to the Burmese army in January 1996, Khun Sa now lives in secluded luxury in Rangoon under the protection of the military. Despite fervid protests and calls for extradition by the United States, Khun Sa has a variety of investments including transportation, hotels, and banking. It has alsobeen alleged by some familiar with narcotics in the region that he continues his old interests in the drug trade through intermediaries-although in a diminished capacity. Such allegations have been firmly denied by the government of Myanmar. However, Burmese denials carry little credibility with Western governments such as Great Britain, which has accused the Myanmar regime of profiting directly from the drug trade. ${ }^{21}$

Mandalay in Burma shows the heavy investment of Chinese from the traditional opium region of Kokang, and the gambling centre of Ruili across the border in China has also profited from Kokang Chinese investment. This investmenthas attracted minority women from Burma to provide sexual services to Chinese men visiting Ruili for gambling, and these women, in turn, repatriate money to their families in Burma.

A study for the United Nations International Drug Control Program (UNDCP) concluded-no doubt with someembarrassment-that "the effects of the illicit drug industry on both the balance of trade and the balance of payments of the producer country ... tend to be positive." 22 The study goes on tonote that "under conditions of structural adjustment ...", "... foreign exchange from drug exports may have ... beneficial effects on the economies concerned, mitigating some of the hardship associated with structural adjustment programmes." ${ }^{23}$ Much the same can be said for the sex industry.

It is estimated that sex is a $\$ 22.5$ to $\$ 27$ billion business in Thailand, or between 10 and 14 percent of GDP. ${ }^{24}$ Just as sex and drugs can mitigate the hardships of structural adjustment, so structural adjustment can improve the comparative advantage of the sex and drug industries. It might be well toconsider such unintended consequences when preaching development strategies to the rest of the world.

\section{Notes}

1. "Asia: Social Backlash," Business Week, 17 August 1998, 19.

2. P. Omerod, The Death of Economics (London: Faber \& Faber, 1994), 3.

3. M. Feldstein, "Refocusing the IMF," Foreign Affairs (March/April 1998): 20-33.

4. For the purposes of this paper, the Upper Mekong region includes Thailand, Burma (Myanmar), the Lao PDR, and Yunnan, China. It should be noted, however, that many of the cross-border issues discussed apply equally to Vietnam and Cambodia, as well. There is a steady flow of girls and women for sex work from Vietnam into Cambodia, from Cambodia into Thailand, from Vietnam into China, and from China into Vietnam. In one border town, Chinese men prefer Vietnamese girls, while Vietnamese men prefer Chinese girls.

5. J. Gray, "HIV/AIDS in The Hills: A Crisis Just Waiting to Happen," paper delivered to the 5th International Thai Studies Conference, SOAS, University of London, 1993.

6. Material on HIV / AIDS is derived from interviews with health officials and researchers in China, Thailand, Burma, and Laos, as well as UNAIDS.

7. China Ministry of Health and UN Theme Group on HIV/AIDS in China, China Responds to AIDS: HIV/AIDS Situation Report and Needs Assessment, Beijing, 1997.

8. C. Beyrer, War in the Blood: Sex, Politics and AIDS in Southeast Asia (Bangkok: White Lotus, 1998).

9. See, for example, recent television reports that the U.S. Justice Department cracked a ring that had smuggled over 12,000 peopleinto the United States, who were forced to work in conditions of virtual servitude.

10. For a recent example, the Economic and Social Commission for Asia and the Pacific (ESCAP) hosted a Regional Conference on Trafficking in Women. Similar conferences have been convened over the last eighteen months by the Mekong Regional Law Centre, the ILO, and organizations in the Philippines, not to mention several major conferences and workshops in South Asia and Europe.

11. United Nations Children's Fund (UNICEF), Children and Women in Myanmar: A Situation Analysis, Rome (New York: UNICEF, 1995).

For example, in discussing the estimated 20,000 to 30,000 "girls" from Burma working in Thai brothels, this report states that "the majority are between 12 and 25 years old." (39, my emphasis) _a rather broad range when considering issues related to 
sex, and one that obscures more than it clarifies.

12. The United Nations Convention on the Rights of the Child, signed by every country except Somalia and the United States, defines "child" in Article 1 as "every human being below the age of 18 years unless under law applicable to the child, majority is attained earlier."

child, majority is attained earlier."
This seems quite straightforward. HowThis seems quite straightforward. How-
ever, as Lim emphasizes in her survey of ever, as Lim emphasizes in her survey of child prostitution, "There are various complications when applying this age criterio examples from Indonesia and Malaysia, see:

L. L. Lim, "Child Prostitution," in The Sex Sector: The economic and Social Bases ofProsSector: The economic and Social Bases ofPros-
titution in Southeast Asia, edited by L. L. titution in Southeast Asia, edited

Lim (Geneva: ILO, 1998), 170-205.
13. H. Montgomery, "Children, Prostitution, and Identity: A Case Study from a Touris Resort in Thailand," in Global Sex Workers: Rights, Resistance, and Redefinition, edited by K. Kempadoo and J. Doezema (London: Routledge, 1998), 13950.

Montgomery presents an important, empirically-based actor-centred critique of standard international discourse on child prostitution. As she states, "... despite the passion that child prostitution arouses, the children themselves have been largely silent. Many people are speaking in their name but very few people have listened to perceive what they do" (p. 150).
14. P. Tongudai, "Women, Migration and Employment-A Study of Migrant Worker in Bangkok" (Ph.D. dissertation, New York University, New York, 1982).

15. P. Pongpaichitetal., Guns, Girls, Gambling and Ganja: Thailand's Illegal Economy and Public Policy (Chiangmai: Silkworm Books, 1998), 214 n. 5.

16. For the relationship of the decline of the upland economy to the entry of highland women into the sex industry, see:

D. A. Feingold, "The Hell of Good Intentions: Some Preliminary Thoughts on Opium in the Political Ecology of the Trade in Girls and Women," in South China and Mainland S.E. Asia: Cross Border Relations in the Post-Socialist Age, edited byG. Evans (In press, 1997).

17. S. Watanabe, "From Thailand to Japan: . S. Watanabe, "From Thailand to Japan:
Migrant Sex Workers as Autonomous Subjects," in Global Sex Workers: Rights, Resistance, and Redefinition, edited by $\mathrm{K}$. Kempadoo and J. Doezema (London: Routledge, 1998), 114-23.

18. Both the overseas Chinese and the overseas Indian communities have mavea tration systems for centuries, which have allowed systems for centuries, which have allowed the efficient transfer of funds and credi
over long distances and across borders. These informal systems are virtually impenetrable to outsiders. However, it is known that the Chinese systems play an important role in drug trafficking and, it now appears, in the trade in women as well.
19. Bangkok Post,S June 1997

20. DuringoneofmyinterviewswithKhunSa, before he was expelled from his headquarters at Hin Tek in the mountains of Chiangrai Province in Northern Thailand some years ago, one of his men invited me to come and see "the lake." I pointed out that nearest lake was in Payao, a considerable distance away. He laughed, and explained that they were making a lake for the resort hotel they were going to build. Khun Sa later said that he wanted to stock the lake with fish-he had read thatforeigners liked to wo fishing and wondered what he should call the hotel. We joked about "The Kingpin Hilton."

21. British Foreign Secretary Robin Cook condemned Myanmar as "... one of the few governments in the world whose members are prepared to profit out of the drugs trade rather than seek to suppress the drugs trade," (The Nation, 3 September 1997).

22. UNDCP, Economic and Social Consequences of Drug Abuseand Illicit Trafficking, UNDCP Technical Series \#6, Vienna, 1997,25.

23. Ibid., 26.

24. L. L. Lim, "The Economic and Social Bases of Prostitution in Southeast Asia," in The Sex Sector: The economic and Social Bases of Prostitution in Southeast Asia, edited by L. L. Lim (Geneva: ILO, 1998), 10. LJ

\section{Asylum: AMoral Dilemma}

\section{By w. Gunthe;r .Plaut}

Toronto: York Lanes Press, ISBN 1-55014-239-9;192 pages, indexed; \$19.90.

Every year the refugee landscape changes, but only in that more problems are added, fewer are solved, and all become constantly more urgent. Fuelled by the explosion of the world's population, the quest for asylum is one of the most pressing problems of our ag ;R(;!Nf? ir.tI pati0I1S-19 atedtrequ tly, but bYM me QSexdusively, in the Westemworld,......haveto respond to masses ofhp.manity eatMing \{ornewlivablehoInes. Human compi'issionJor these refugees can be found everywhere, but so can xenophobia and th(;! deSir(;!topreserve one's nation, economic well being, and cultural integrity. The dash between these impulses represents one of the great dilemmas of our time and is the subject of Plaut's study. In exploring it, he provides a far-ranging inquiry into the human condition.

rhepoo tSpoli cal,.efly:Uc,.phnoSQphical, rel@p'US,and.soqiolbgkal argUmentS, and deals with spme of them.ost troublesome and heartbreakiJ:tg conflicts ill the news.

Contents: ThelsSJleSiQuestions Without Answers; Definitions; Religion, Natural Law, and Hospitality; A Look at History; Some Ethical Questions; Through the tens of Sociobiology; Community and b:Idividual; Contended Rights: To Leave, Return, Remain; 'fJutJ?ract:iff;:R MIM cil.; Fqp,r an.LiU1ds;GliInp \$ of Europei'ind CentralAInerica; Tl1j!Nprtl1 American Experience; The Sari a1'YMovetnent;A FinalLoQk; Bibliography; Index.

AsY !Im.A Mol'izl Dile;mma is simultaneously published in the United States by Praeger Publishers, and in Canada by York Lanes Pte\$S.

4P9\#qkltfrom; Cen.ti'ef()tRef11g(!eStudi s Fax:

(416) 736-5837• Email: refuge@yorku.ca 